\title{
Analisis Kesulitan Belajar : Dampak Latar Belakang Kejuruan ditinjau dari Proses Pembelajaran Matematika Perguruan Tinggi
}

\author{
Muhammad Yasin ${ }^{1}{ }^{*}$, Netriwati ${ }^{1}$ \\ 1Universitas Islam Negeri Raden Intan Lampung. Jalan Endro Suratmin, Sukarame, Bandar \\ Lampung35133, Indonesia. \\ *Corresponding Author. E-mail: yasin.sakarepku@gmail.com
}

\begin{abstract}
Abstrak
Tujuan penelitian ini adalah melakukan diagnosis kesulitan belajar mahasiswa Pendidikan Matematika lulusan IPA, IPS dan SMK ditinjau dari pembelajaran matematika. Penelitian ini menggunakan jenis penelitian deskritif kualitatif. Instrumen yang digunakan berupa hasil wawancara, hasil observasi pembelajaran mahasiswa matematika dan didukung hasil angket minat belajar mahasiswa pendidikan matematika dengan menggunakan alat ukur skala Likert yang digunakan untuk mengukur sikap, pendapat, ataupun persepsi seseorang tentang fenomena sosial. Hasil penelitian ini antara lain: (1) Jenis kesulitan belajar mahasiswa dengan lulusan IPA termasuk kesulitan belajar akademik (academic learning disabilities). (2) Jenis kesulitan belajar mahasiswa dengan latar belakang IPS dan SMK memiliki jenis kesulitan belajar yang berhubungan dengan perkembangan (developmental learning disabilities) yang mencakup persepsi, kesulitan belajar bahasa dan komunikasi, serta kesulitan belajar dalam penyesuaian perilaku sosial. (3) upaya yang harus dilakukan untuk mengatasi hal tersebut adalah menumbuhkan minat belajar yang tinggi kepada mahasiswa.
\end{abstract}

Kata Kunci: Diagnosis kesulitan belajar; Lulusan IPA IPS dan SMK; Proses Pembelajaran Matematika

\begin{abstract}
The purpose of this study is to make a diagnosis of student learning difficulties Mathematics education graduate IPA, IPS and SMK in terms of learning mathematics. This research uses descriptive qualitative research type. Instrument used in the form of interview result, observation result of student learning mathematics and supported by result of questionnaire of interest of student of mathematics education by using Likert scale measurement which used to measure attitude, opinion, or perception of someone about social phenomenon. The results of this study include: (1) Types of learning difficulties for students with science graduates including difficulties in academic learning (academic learning disabilities). (2) Types of learning difficulties students with social studies and vocational backgrounds have a type of learning difficulties related to development (developmental learning disabilities) which includes perceptions, difficulties in language learning and communication, and learning difficulties in adjusting social behavior. (3) the effort that must be made to overcome this is to foster a high interest in learning to students.
\end{abstract}

Keywords: Diagnosis of learning difficulties; IPA IPS and SMK graduates; Mathematics Learning Process

PENDAHULUAN

$\begin{array}{ccc}\text { Bagi } & \text { sebagian besar orang } \\ \text { terutama } & \text { bagi mereka yang }\end{array}$ kesehariannya melakukan proses belajar mengajar baik itu di sekolah maupun di luar sekolah, kata pendidikan merupakan suatu yang tidak asing lagi. Karena pendidikan adalah hal penting yang harus didapatkan di dunia ini guna terwujudnya masa depan yang cerah bagi seseorang (Lestari, Meter, \& Negara, 2015). 
Proses pendidikan tidak dapat dipisahkan dari proses pembelajaran. Perspektif mengajar dilakukan oleh guru/pendidik, ataupun pihak yang mendidik (Syazali, 2015). Proses pembelajaran bukan hanya kegiatan mentransfer ilmu dari guru kepada siswanya, namun dalam proses pembelajaran guru bertanggung jawab untuk mendampingi dan membimbing siswa agar dapat menguasai materi pembelajaran dengan baik dan tuntas (Winiari, Meter, \& Negara, 2015).

Salah satu mata pelajaran yang dianggap sangat penting dalam dunia pendidikan di Indonesia adalah matematika (Lamote, 2017). Matematika adalah pembelajaran yang terstruktur dalam proses pembelajarannya, terorganisasi, dan berjenjang, artinya terdapat hubungan antara materi satu dengan yang lainnya (Widyastuti, 2015). Ketercapaian pendidikan matematika dapat dilihat dari siswa mampu menyelesaikan tugas-tugas belajar matematika, siswa mampu menerapkan tujuan pendidikan matematika dalam kehidupan sehari, mengaplikasikannya, menjadikan matematika bagian penting dalam kehidupan siswa (Hasibuan, 2018).

Penyelenggaraan Programme for International Student Assessment (PISA) tahun 2012 secara umum menyimpulkan bahwa prestasi siswa dibidang Matematika sangat menentukan keberhasilan dan kemajuan bangsa, baik itu dalam peningkatan kualitas pendidikan maupun dalam partisipasi politik (Putra, Jampel, \& Sudarma, 2015). Prestasi belajar yang rendah merupakan salah satu bukti adanya kesulitan

dalam belajar siswa, pendidik dalam hal ini adalah orang yang bertanggung jawab yang seharusnya dapat memahami kesulitan belajar anak didiknya dan kemudian memberikan bantuan pemecahannya (Jamal, 2014; Widyasari, Meter, \& Negara, 2015). Hal yang sangat penting diselesaikan adalah dalam pemecahan masalah, itu sebagai jantungnya dalam pembelajaran matematika (Masykur, Nofrizal, \& Syazali, 2017).

Kegiatan proses pembelajaran yang ada di UIN Raden Intan Lampung salah satunya dapat ditemui di Program Studi Pendidikan Matematika. Program Studi Pendidikan Matematika memiliki mahasiswa yang berlatar belakang pendidikan berbeda-beda, beberapa diantaranya adalah dari program Ilmu Pengetahuan Alam (IPA), Ilmu Pengetahuan Sosial (IPS), dan Sekolah Menengah Kejuruan (SMK). Hal tersebut dapat dilihat dari jumlah mahasiswa angkatan tahun 2016 dan 2017 pada Program Studi Pendidikan Matematika. Adapun jumlah peminat dengan latar belakang pendidikan berbeda dapat dilihat pada tabel berikut:

Tabel 1. Latar Belakang Pendidikan Mahasiswa Pendidikan Matematika Angkatan Tahun 2016 dan 2017

\begin{tabular}{llllll} 
NO & ANGKATAN & KELAS & $\begin{array}{l}\text { LULUSAN } \\
\text { IPA }\end{array}$ & IPS & SMK \\
1 & 2016 & D & 18 & 5 & 4 \\
2 & 2017 & A & 26 & 1 & 1 \\
& & B & 22 & 6 & 1 \\
& & C & 22 & 5 & 2 \\
& & JUMLAH & 70 & 12 & 4 \\
\hline
\end{tabular}


Berdasarkan Tabel 1, dapat diketahui bahwa jumlah terbanyak untuk latar belakang pendidikan adalah pada lulusan dengan jurusan IPA, namun lulusan IPS dan SMK lebih 20\% orang. Ini menunjukkan bahwa Program Studi Pendidikan Matematika tidak hanya diminati oleh lulusan eksakta, namun lulusan non-eksakta dan kejuruan. Hal ini yang mengakibatkan perbedaan individu dan pemahaman awal mahasiswa untuk menempuh studi di Pendidikan Matematika. Perbedaan individual menyebabkan perbedaan tingkah laku atau pola belajar dikalangan mahasiswa. Kesulitan belajar didasarkan pada sikap psikologis, sosiologis, dan fisiologis yang dapat mempengaruhi hasil belajar mahasiswa atau capaian tujuan pembelajaran.

Sesuai dengan pedoman akademik dan kode etik mahasiswa UIN Raden Intan Lampung tahun 2016 pasal 34 tentang tata cara penetapan nilai akhir semester dengan ketentuan huruf mutu D berstatus lulus namun disarankan untuk mengulang dan huruf mutu E dinyatakan tidak lulus dan diwajibkan untuk mengulang. Berikut ini daftar jumlah mahasiswa yang memperoleh nilai $\mathrm{D}$ dan E pada mata kuliah Kalkulus I, Aljabar Linier I, dan Analisis Real I pada Prodi Pendidikan Matematika angkatan 2014 dan 2015.

Tabel 2. Daftar Nilai D dan E Mahasiswa PMTK 2014 dan 2015

\begin{tabular}{lllll}
\hline \multirow{2}{*}{ Mata Kuliah } & \multicolumn{2}{l}{ Angkatan 2014 } & \multicolumn{2}{l}{ Angkatan 2015 } \\
& Nilai D & Nilai E & Nilai D & Nilai E \\
Kalkulus I & 25 & 0 & 32 & 0 \\
Aljabar Linier I & 7 & 4 & 14 & 0 \\
Total & 32 & 4 & 46 & 0 \\
\hline
\end{tabular}

Pada Tabel 2 dapat dilihat bahwa sampel sebanyak 32 yang memperoleh nilai $\mathrm{D}$ dan 4 responden yang mendapat nilai E pada angkatan 2014 sedangkan pada angkatan 2015 sebanyak 46 responden yang mendapatkan nilai $\mathrm{D}$ dan tidak terdapat satupun responden yang memperoleh huruf mutu E. Dari beberapa permasalahan di atas, sehingga perlu dilakukan diagnosa untuk mengetahui penyebab kegagalan mahasiswa dalam pencapaian tujuan pembelajaran. Hal ini didasari bahwa pengetahuan mahasiswa dalam menyelesaikan masalah memerlukan waktu yang terus berproses dalam memecahkannya (Maroni R Nyikahadzoyi, 2013). Penelitian Nursalam (2016) menyatakan bahwa yang perlu menjadi perhatian khusus pendidik dalam pembelajaran matematika adalah pemahaman tentang konsep, fakta, prinsip, dan operasi dalam matematika.
Selain itu, ditemukan bahwa pada umumnya mahasiswa mengalami kesulitan belajar, hal ini banyak dijumpai pada mahasiswa yang berlatar belakang jurusannya di SLTA adalah jurusan noneksakta dan kejuruan. Materi yang diajarkan jauh lebih sulit dibanding pada saat sekolah menengah, karena sebelumnya materi yang disampaikan belum pernah didapatkan di sekolah menengah.

Kesulitan belajar (learning disability) ialah ketidakmampuan belajar yang terjadi pada anak dan dimanifestasikan oleh kesulitan belajar keterampilan dasar seperti menulis, membaca dan matematika (Najmi, 2014; Razak, 2014). Kesulitan belajar yang dialami oleh mahasiswa dapat terlihat dari karakteristik yang dimiliki oleh mahasiswa itu sendiri, karakteristik kesulitan belajar yang ditunjukkan oleh mahasiswa sangat beragam pada setiap 
mata pelajaran sesuai dengan dengan materi yang diajarkan (Sunariah \& Rijal, 2017).

Menurut Lerner dalam (Darjiani, Meter, \& Negara, 2015), kesulitan belajar matematika dapat ditinjau dari penguasaan tiga elemen yaitu: (1) konsep dengan indikator kesulitan dalam menentukan rumus untuk menyelesaikan suatu masalah atau peserta didik dalam menggunakan teorema atau rumus tidak sesuai dengan kondisi prasyarat berlakunya rumus tersebut atau tidak menuliskan teorem (2) keterampilan dengan indikator-indikator peserta didik kesulitan menggunakan operasi dasar dalam penjumlahan, pengurangan, perkalian, pembagian, perhitungan akar dan kuadrat (3)

pemecahan masalah dengan indikator siswa tidak dapat melanjutkan pekerjaannya dalam menyelesaikan soal.

Beberapa faktor-faktor kesulitan belajar telah diketahui sesuai hasil penelitian sebelumnya yang dilakukan oleh (Darjiani et al., 2015; Manalu, Meter, \& Negara, 2015; Yuliardi, 2017) dalam penelitiannya didapatkan bahwa faktorfaktor yang mempengaruhi kesulitan belajar adalah minat dan motivasi, faktor guru, faktor lingkungan sosial dan faktor kurikulum; (Abrar, 2014) dalam penelitiannya kesulitan siswa mempelajari matematika dapat dilihat dari cara menggunakan konsep dan prinsip; (Murni, Ali, \& Kurnila, 2018) dalam penelitiannya kesulitan belajar disebabkan oleh ingatan yang lemah, materi yang diajarkan tidak terkait dengan kehidupan sehari-hari siswa, dan kurangnya kemampuan prosedural, konseptual, dan faktual.

Berdasarkan hal tersebut, akan sangat menarik untuk dapat diketahui sejauh mana mahasiswa mengalami kesulitan belajar, dan dapat juga diagnosis kesulitan belajar mahasiswa menurut jenis-jenis kesalahannya dalam proses pembelajaran. Dengan demikian peneliti bermaksud akan melakukan diagnosis kesulitan belajar mahasiswa Pendidikan Matematika lulusan IPA, IPS dan SMK ditinjau dari pembelajaran matematika.

\section{METODE}

Dalam penelitian ini penulis menggunakan jenis penelitian deskritif kualitatif. Menurut Sugiyono bahwa penelitian kualitatif dapat diartikan sebagai metode penelitian yang berdasarkan pada filsafat post positivisme, digunakan untuk meneliti pada kondisi objek alamiah, (eksperimen) dimana peneliti adalah instrumen kunci, teknik pengumpulan data dilakukan secara triangulasi (gabungan), analisis data bersifat induktif/kualitatif, dan hasil penelitian kualitatif lebih menekankan makna dari pada generalisasi (Sugiyono, 2011). Instrumen yang digunakan dalam penelitian ini menggunakan instrumen bantu berupa hasil wawancara, hasil observasi pembelajar mahasiswa matematika dan didukung hasil angket minat belajar mahasiswa pendidikan matematika dengan menggunakan alat ukur skala Likert yang digunakan untuk mengukur sikap, pendapat, ataupun persepsi seseorang tentang fenomena sosial.

Sumber data dalam Penelitian kualitatif dipilih secara purposive dalam artian pengambilan sempel dengan tujuan tertentu dari peneliti dan bersifat snowball sampling. Tehnik pengumpulan data adalah dengan cara melalui observasi, wawancara, angket dan dokumen. Tehnik analisis data yang digunakan karna proses berkelanjutan yang membutuhkan refleksi terusmenerus dalam data, mengajukan pertanyaan-pertanyaan analitis, dan menulis catatan singkat sepanjang penelitian sehingga langkah-langkah tehnik analisis data adalah :

1. Data Reduction (Reduksi Data) 
Reduksi data adalah proses berfikir sensitif yang memerlukan kecerdasan dan keleluasaan kedalaman wawasan yang tinggi. Sehingga data yang telah direduksi akan memberikan gambaran yang jelas, dan mempermudah peneliti untuk melakukan pengumpulan data selanjutnya, dan mencarinya bila diperlukan.

2. Data Display (penyajian data)

Penyajian data dapat diartikan sebagai usaha untuk menyusun sekumpulan informasi yang telah diperoleh dilapangan dengan menyajikan data tersebut secara jelas dan sistematis sehingga akan memudahkan peneliti dalam mengambil keputusan. Dalam penelitian ini data akan disajikan dalam bentuk teks yang bersifat naratif berisi kegiatan pengklafikasian data, yaitu menulis kumpulan data yang terorganisir dalam kalimat yang disusun secara logis dan sistematis serta dapat dilakukan penarikan kesimpulan dari data tersebut dan memberi gambaran yang jelas tentang hasil penelitian.

3. Conclusion Drawing/verification (Penarikan kesimpulan)

Langkah terakhir yaitu menarik kesimpulan. Kesimpulan sementara diambil dari data kuesioner dan wawancara pada setiap kategori. Data ini dapat menentukan penyebab kesulitan belajar yang dialami peserta didik jurusan matematika. Kesimpulan yang diharapkan dalam penelitian kualitatif merupakan temuan yang baru. Temuan dapat berupa deskripsi atau gambaran suatu objek yang sebulumnya masih belum jelas sehingga data yang diteliti menjadi lebih jelas.

Berdasarkan uraian di atas, dalam menganalisa data ini digunakan cara berfikir sintetik dalam mengambil kesimpulan analisis dengan jalan induktif yaitu bertitik tolak pada pengetahuan atau pendapat individu dan dirangkaikan sehingga menjadi pengetahuan yang sifatnya umum yang ditentukan dari hasil persentase yang paling besar, sehingga dengan cara ini akan menghasilkan suatu kesimpulan yang objektif dan dapat dijadikan sebagai fakta untuk membuktikan kebenaran hipotesis. Pada kegiatan ini nantinya akan menghasilkan deskripsi mengenai diagnosis kesulitan belajar mahasiswa matematika.

\section{Validitas Data atau Keabsahan Data}

Validitas adalah tingkat ketepatan antara data yang terjadi pada objek penelitian dengan data yang dilaporkan oleh peneliti. Data yang valid merupakan data yang tidak berbeda antara data yang dilaporkan oleh peneliti dengan data yang sesungguhnya terjadi pada obyek penelitian sehingga data bisa dikatakan valid jika instrumen yang digunakan sesuai dengan yang di ukur. Dalam penelitian yang bersifat kualitatif, temuan atau data dapat dinyatakan valid, apabila tidak terdapat perbedaan antara yang dilaporkan peneliti dengan apa yang sesungguhnya terjadi pada obyek yang diteliti.

Pengujian keabsahan data yang digunakan dalam penelitian kualitatif, yaitu derajad kepercayaan (credibility), keteralihan (transferability), kebergantungan (dependability), dan kepastian (confirmability). Uji keabsahan dalam penelitian ini menggunakan uji kredibilitas. Uji kredibilitas data atau kepercayaan terhadap data hasil penelitian terdapat berbagai macam cara. Cara yang digunakan dalam penelitian ini adalah triangulasi. Triangulasi dalam pengujian kredibilitas ini diartikan sebagai pengecekan data dari berbagai sumber dengan berbagai cara, dan berbagai waktu. Sehingga terdapat beberapa jenis triangulasi yaitu triangulasi sumber, triangulasi teknik pengumpulan data, dan triangulasi waktu. Dokumentasi dan wawancara dalam 
penelitian ini merupakan dua teknik pengumpulan data (alat ukur) yang utama, karena mempunyai kesahihan dan keandalan yang tinggi dan mampu menjaring data verbal dan nonverbal tentang aspek manusia. Untuk mengurangi kelemahan masing-masing teknik yang disebabkan oleh faktor peneliti sebagai instrumen kunci. Kedua teknik tersebut dapat digunakan secara tumpang tindih sehingga keabsahan dan kendalanya dapat ditingkatkan. Ataupun dapat pula ditingkatkan dengan triangulasi menggunakan angket sehingga data yang diperoleh akan valid dan keabsahan data juga tinggi sehingga pada penelitian ini, uji kredibilitas data hasil penelitian dilakukan dengan triangulasi teknik yang berarti peneliti menggunakan teknik pengumpulan data yang berbeda-beda untuk mendapatkan data dari sumber yang sama.

\section{HASIL DAN PEMBAHASAN}

Dari hasil observasi tersebut diduga kesulitan belajar tidak hanya didominasi oleh mahasiswa matematika yang memiliki latar belakang pendidikan nonesakta namun mahasiwa yang berlatar belakang eksakta pun mengalami kegagalan dalam pencapaian tujuan pembelajaran. Kemampuan awal mahasiswa yang berlatar belakang eksakta memang sedikit lebih baik dari pada mahasiswa yang berlatar belakang noneksakta seperti terlihat pada gambar
4.2 dan gambar 4.3 pada saat awal proses pembelajaran dosen memberikan pre-tes terkait pengetahuan awal tentang matematika, mahasiswa berlatar belakang eksakta (IPA) lebih mendominasi sedangkan mahasiswa matematika yang berlatar belakang noneksakta (IPS dan SMK) hanya sedikit mengetahui materi yang akan diberikan.

Pada saat proses pembelajaran berlangsung, minat mahasiswa yang berbeda-beda yang membuat tingkat pemahaman pada materi yang diberikan juga berbeda. Dari hasil angket minat belajar mahasiswa matematika semester 1 pada mata kuliah matematika dasar dan mahasiswa matematika semester 3 pada mata kuliah kalkulus 2 diperoleh bahwa minat belajar mahasiswa tidak hanya mahasiswa berlatar belakang noneksakta yang memiliki kategori minat belajar rendah, pada tabel 4.1-4.4 terlihat bahwa ada beberapa mahasiswa yang berlatar belakang eksakta memiliki kategori minat belajar rendah. Didukung dengan analisis hasil wawancara dari responden yang berlatar belakang berbeda diperoleh bahwa penyebab kesulitan belajar yang responden rasakan berbeda-beda selain latar belakang noneksakta tetapi juga disebabkan minat mereka yang rendah yang menyebabkan mereka malas dalam belajar sehingga hasil yang diperoleh kurang maksimal. 
Desimal, 2 (1), 2019 - 65

Muhammad Yasin, Netriwati

Tabel 3. Kesesuaian Kegagalan Belajar dengan Minat Belajar MD dan Kl

\begin{tabular}{cccc}
\hline Inisial Nama & Lulusan & Nilai UTS & Kategori Minat Belajar \\
DA & IPA & 6 & RENDAH \\
PAN & IPA & 5 & RENDAH \\
SSR & IPA & 71 & SEDANG \\
WTH & IPA & 4 & RENDAH \\
MRO & IPA & 98 & TINGGI \\
DGA & IPA & 3 & RENDAH \\
ITR & IPS & 51 & SEDANG \\
FY & IPS & 73 & TINGGI \\
LM & IPS & 71 & TINGGI \\
SA & IPS & 4 & RENDAH \\
IG & IPS & 41 & SEDANG \\
FNH & IPS & 9 & RENDAH \\
CFY & SMK & 5 & RENDAH \\
IA & SMK & 14 & RENDAH \\
FA & SMK & 25 & SEDANG \\
DDD & IPA & 100 & TINGGI \\
LLH & IPA & 50 & SEDANG \\
SF & IPA & 16,67 & RENDAH \\
AK & IPS & 2 & RENDAH \\
NM & IPS & 55 & SEDANG \\
AM & SMK & 66,68 & TINGGI \\
MR & SMK & 16,67 & SEDANG \\
\hline
\end{tabular}

Berdasarkan Tabel 3 dapat diketahui bahwa kegagalan dalam pencapaian tujuan hasil pembelajaran tidak hanya disebabkan oleh latar belakang noneksakta, namun mahasiswa dengan latar belakang eksakta yang memiliki minat belajar rendah juga mengalami kegagalan dalam pencapian hasil pembelajaran. Berdasarkan hasil observasi yang dilakukan, mahasiswa yang memiliki minat belajar dengan kategori rendah terlihat bahwa mengalami kesulitan dalam memahami materi seperti terlalu lama dalam proses menghitung, tidak cepat dalam memahami konsep dari materi tersebut, dan mahasiswa tidak terlalu memperhatikan dosen saat proses pembelajaran berlangsung. Sehingga dapat dikategorikan jenis kesulitan belajar mahasiswa dengan lulusan IPA termasuk kesulitan belajar akademik (academic learning disabilities).Kesulitan belajar akademik merupakan kesulitan belajar yang menunjukan adanya kegagalankegagalan pencapaian prestasi akademik yang sesuai dengan kapasitas yangdiharapkan, karena diperkirakan mahasiswa dengan latar belakang IPA sudah memiliki modal dasar pengetahuan yang lebih baik seharusnya lebih cepat dalam memahami konsep materi yang disampaikan dibandingkan dengan mahasiswa dengan lulusan IPS dan SMK yang sedikit lebih lama dalam pemahaman konsep. Mahasiswa dengan latar belakang IPS dan SMK memiliki jenis kesulitan belajar yang berhubungan dengan perkembangan (developmental learning disabilities) yang mencakup persepsi, kesulitan belajar bahasa dan komunikasi, kesulitan belajar dalam penyesuaian perilaku sosial sehingga mengakibatkan penggunaanstrategi perhitungan matematika yang lebih lama, keterlambatan dalam belajar prosedur matematika, kesulitan mengambil faktafakta dasar. Dari hasil triangulasi teknik diperoleh bahwa penyebab kesulitan belajar mahasiswa matematika pada mata kuliah matematika dasar dan kalkulus 2 bukan hanya disebabkan oleh latar belakang lulusan ( IPA, IPS, dan SMK) namun lebih didominasi oleh 
minat belajar. Senada dengan hasil di atas terlihat bahwa ketika mahasiswa memiliki minat belajar yang rendah maka akan mengalami kesulitan dalam belajar begitupun sebaliknya ketika mahasiswa yang memiliki minat belajar yang tinggi walaupun dari latar belakang noneksakta masih dapat mencapai tujuan dari pembelajaran tersebut dengan baik.

Adapun beberapa upaya yang harus dilakukan untuk mengatasi hal tersebut adalah menumbuhkan minat dalam belajar karena pada minat belajar mahasiswa terdapat perbedaan hasil belajar antara minat belajar tinggi, sedang dan rendah. Untuk mahasiswa yang memiliki kategori minat belajar rendah akan mengalami kesulitan dalam proses pembelajaran. Hal ini menunjukan bahwa kesulitan belajar mahasiswa matematika disebabkan oleh minat belajar mahasiswa tersebut.Sehingga untuk pembelajaran selanjutnya diperlukan pembelajaran yang dapat menarik minat mahasiswa dalam belajar seperti membuat perasaan senang atau tidak tegang, bahan ajar yang mudah dipahami, dan lebih memperhatikan mahasiswa yang mengalami keterlambatan dalam pemahaman materi, memberi penghargaan berupa pujian dimana keberadaan mahasiswa dapat diakui oleh teman-teman dalam kelasnya. Jika mahasiswa sudah memiliki minat tinggi, sekalipun memiliki latar belakang yang berbeda, hasilnya pasti akan lebih baik. Oleh karena itu dalam proses belajar mengajar dosen harus memahami terhadap situasi kelas dan lebih memotivasi mahasiswa yang berlatar belakang noneksakta agar lebih semangat dalam belajar. Oleh karena itu dosen harus memiliki metode belajar yang cocok dan sesuai dengan pengetahuanmateri para mahasiswanya artinya dosen harus memahami kebutuhan dan perkembangan mahasiswanya sehingga tidak terdapat kesenjangan antara mahsiswa dengan latar belakang eksakta maupun mahasiswa dengan latar belakang noneksakta.

\section{SIMPULAN DAN SARAN}

Berdasarkan landasan teori dan didukung dengan hasil analisis data serta mengacu pada perumusan masalah yang telah diuraikan, maka disimpulkan bahwa (1). Jenis kesulitan yang didapat pada mahasiswa dengan lulusan IPA adalah Kesulitan belajar akademik (academic learning disabilities), kesulitan belajar yang menunjukan bahwa adaya kegagalan dalam pencapaian prestasi akademik yang tidak sesuai dengan kapasitas yang diharapkan. (2). Jenis kesulitan yang didapat pada mahasiswa dengan lulusan IPS dan SMK adalah kesulitan belajar yang berhubungan dengan perkembangan (developmental learning disabilities) yang mencakup gangguan terhadap penggunaan strategi dalam menghitungan yang lebih lama dari pada mahasiswa lain, keterlambatan dalam memahami prosedur matematika, serta mengalami kesulitan dalam mengambil fakta-fakta dasar. (3). Penyebab kesulitan belajar mahasiswa matematika lulusan IPA, IPS, dan SMK tidak hanya disebabkan oleh latar belakang mahasiswa melainkan didominasi oleh minat belajar mereka yang rendah sehingga upaya yang harus dilakukan adalah menciptakan suasana belajar yang lebih inovatif sehingga menumbuhkan minat dalam belajar yang lebih besar dan mahasiwa dapat menumbuhkan motivasi pada diri agar menumbuhkan minat belajar yang tinggi serta semangat dalam belajar. 


\section{DAFTAR PUSTAKA}

Abrar, A. I. P. (2014). Kesulitan Siswa SMP Belajar Konsep Dan Prinsip Dalam Matematika. Al-Khwarizmi, 2(1), 59-68.

Darjiani, N. N. Y., Meter, I. G., \& Negara, I. G. A. O. (2015). Analisis KesulitanKesulitan Belajar Matematika Siswa Kelas V Dalam Implementasi Kurikulum 2013 Di SD Piloting SeKabupaten Gianyar Tahun Pelajaran 2014/2015. E-Journal PGSD Universitas Pendidikan Ganesha, 3(1).

Hasibuan, E. K. (2018). Analisis Kesulitan Belajar Matematika Siswa Pada Pokok Bahasan Bangun Ruang Sisi Datar Di SMP Negeri 12 Bandung. AXIOM, VII(1), 18-30.

Jamal, F. (2014). Analisis Kesulitan Belajar Siswa Dalam Mata Pelajaran Matematika Pada Materi Peluang Kelas XI Ipa SMA Muhammadiyah Meulaboh Johan Pahlawan. Jurnal MAJU OJurnal Pendidikan Matematika), 1(1), 18-36.

Lamote, H. (2017). Kesulitan-Kesulitan Guru Matematika Dalam Melaksanakan Pembelajaran Kurikulum 2013 Di Madrasah Aliyah Ddi Labibia. Jurnal Al-Ta'dib, 10(1), 55-72.

Lestari, N. P. L. D., Meter, I. G., \& Negara, I. G. A. O. (2015). Analisis KesulitanKesulitan Belajar Bahasa Indonesia Siswa Kelas IV Dalam Implementasi Kurikulum 2013 Di SD Piloting SeKabupaten Gianyar. E-Journal PGSD Universitas Pendidikan Ganesha, 3(1).

Manalu, R., Meter, I. G., \& Negara, I. G. A. 0. (2015). Analisis KesulitanKesulitan Belajar IPA Siswa Kelas IV Dalam Implementasi Kurikulum 2013 Di SD Piloting Se-Kabupaten Gianyar. E-Journal Mimbar PGSD Universitas Penddidikan Ganesha, 3(1).

Maroni R Nyikahadzoyi, T. M. (2013).
Some Cognitive Obstacles Faced By "A" Level Mathematics Students in Understanding Inequalities: Case Study of Bindura Urban High Schools. International Journal of Academic Research in Progresive Education and Development, 2(1).

Masykur, R., Nofrizal, N., \& Syazali, M. (2017). Pengembangan Media Pembelajaran Matematika dengan Macromedia Flash. Al-Jabar: Jurnal Pendidikan Matematika, 8(2), 177185.

Murni, V., Ali, F. A., \& Kurnila, V. S. (2018). Kesulitan Belajar Matematika Ditinjau Dari Kemampuan Numerik Siswa SLB. Journal of Songke Math, 1(1), 37-46. Najmi, H. (2014). Penggunaan Tabungan Kepingan Sebagai Reward Dalam Meningkatkan Kemampuan Membaca Kata Benda Bagi Anak Berkesulitan Belajar Kelas D.2 Di Sdn 27 Olo Padang Barat. EJUPEKhu, 3(1), 256-264.

Nursalam. (2016). Diagnostik Kesulitan Belajar Matematika: Studi pada Siswa SD/MI di Kota Makassar. Lentera Pendidikan, 19(1), 1-15.

Putra, N. P. S. W., Jampel, I. N., \& Sudarma, I. K. (2015). Analisis Kesulitan Belajar Matematika Siswa Kelas II Pada Implementasi Kurikulum 2013 Di SD SeKecamatan Buleleng. E-Journal PGSD Universitas Pendidikan Ganesha, 3(1).

Razak, A. (2014). Meningkatkan Kemampuan Membaca Permulaan Bagi Anak Kesulitan Belajar Melalui Brain Gym. E-JUPEKhu, 3(1), 234244.

Sugiyono. (2011). Metode Penelitian Kuantitatif Kualitatif dan $R \& D$. Bandung: Alfabeta.

Sunariah, \& Rijal, R. (2017). Analisis Kesulitan Belajar Siswa Pada Pembelajaran Matematika Materi Pecahan. PRIMARY, 9(1), 93-108. 
Desimal, 2 (1), 2019 - 68

Muhammad Yasin, Netriwati

Syazali, M. (2015). Pengaruh Model Pembelajaran Creative Problem Solving Berbantuan Maple II Terhadap Kemampuan Pemecahan Masalah. Al-Jabar: Jurnal Pendidikan Matematika, 6(1), 9198.

Widyasari, N. M. D., Meter, I. G., \& Negara, I. G. A. O. (2015). Analisis Kesulitan-Kesulitan Belajar Matematika Siswa Kelas IV dalam Implementasi Kurikulum 2013 di SDpiloting Se-Kabupaten Gianyar. E-Journal PGSD Universitas Pendidikan Ganesha, 3(1).

Widyastuti, R. (2015). Proses Berpikir Siswa dalam Menyelesaikan Masalah Matematika berdasarkan
Teori Polya ditinjau dari Adversity Quotient Tipe Climber. Al-Jabar: Jurnal Pendidikan Matematika, 6(2), 183-194.

Winiari, I. G. A., Meter, I. G., \& Negara, I. G. A. O. (2015). Analisis KesulitanKesulitan Belajar Bahasa Indonesia Kelas V Dalam Implementasi Kurikulum 2013 Di SD Piloting SeKabupaten Gianyar. E-Journal PGSD Universitas Pendidikan Ganesha, $3(1)$.

Yuliardi, R. (2017). Analisis Terhadap Kesulitan Belajar Matematika Siswa Ditinjau Dari Aspek Psikologi Kognitif. JuMlahku, 3(1), 23-30. 